\title{
REPORT ON SOME TERRESTRIAL MOLLUSCS FROM DIFFERENT REGIONS OF NEPAL
}

\author{
B. R. Subba and T. K. Ghosh
}

\begin{abstract}
Nine species of terrestrial molluscs were collected at eastern, mid western and far western regions of Nepal. The documented molluscan samples are represented with 4 families under three orders. Out of the total record of nine species, four species belonged to the family Ariophantidae, three species to Subulinidae, one species to Bradybaenidae and one to Veronicellidae.
\end{abstract}

Key words: Molluscs, Nepal, record, species, terrestrial.

\section{Introduction}

Nepal is a land of various interest accommodating diverse faunal and floral components. It stands on a latitude of $26^{\circ} 22^{\prime}$ to $30^{\circ} 27^{\prime}$ North and its longitude is between $80^{\circ} 4^{\prime}$ to $88^{\circ} 12^{\prime}$ East. This Himalayan country has broadly been divided into three main distinct regions which includes the lowland (65m to $915 \mathrm{~m}$ ), midland (915m to $2745 \mathrm{~m}$ ) and the highland areas above $2745 \mathrm{~m}$ of elevation to the north.

Relevant literatures regarding the terrestrial molluscs of Nepal are very scarce. GodwinAusten (1910) and Majupuria (1981-1982) have reported a few species of freshwater and terrestrial molluscs from different parts of Nepal including Kathmandu valley. Some notable works were done by Subba and Ghosh (2000), Subba and Ghosh (2001), Subba (2003), Thapa (2003) and Subba and Pandey (2005) who made significant reports of various molluscan species from different parts of the country Pfiffer et al. (1999), Yadav et al. (1980) made interesting studies on the population status of various species of fresh water molluscs of Nepal.

\section{Study Area}

The study sites were selected on the basis of hotspots where rich diversity of molluscs is accommodated. These include some of the parts of llam, Panchthar, Taplejung, Sunsari, Dhankuta and Tehrathum of the eastern region, likewise, Dang, Banke, Kailali and Kanchanpur of the mid western and far western regions respectively. The geographical position, suitable climatic conditions, diverse vegetation and topography of the eastern, mid western and far western regions of the country show interesting variations among molluscan species so these places were preferred for the present study.

\section{Material and Methods}

Samples of terrestrial mollusc were collected during 1999-2003 at different altitudes of $70 \mathrm{~m}$ to $3000 \mathrm{~m}$. Random sampling was done at suitable sites like gardens, fields, forests, rocky and shady places etc. The shells of land molluscs were simply hand picked, cleaned and 
kept safely in containers which then were preserved in $70 \%$ ethanol for further investigation. Natural colour, habits and habitats were duely noted during the time of collection.

Identification of each specimen was made with the help of available literature viz. Cooke et al. (1896) Raut and Ghose (1984), Hymen (1993). Some specimens and coded samples were sent to the Zoological Survey of India (ZSI) Calcutta, for identification and re-confirmation.

\section{Results and Discussion}

The hills and plains of the east display many preferable habitats for diverse species. The land molluscs collected during the survey period are presented in Table -I. The nine species of terrestrial mollusc recorded in the present survey belonged to four families like Bradybaeridae (one species), Subulinidae (3 species), Ariophantidae (four species), and Veronicellidae (one species). Rich diversity of the terrestrial molluscs was found during rainy seasons. The drought season represented dry shells in majority. The moist places occurring near the stream, canals, cascades and lakes represented high rate of diversity of the terrestrial molluscan species, but this is not applicable to every species as there always appeared over lapping phenomenon regarding the distribution of the molluscan species.

Among the recorded species, Aegista (Plectotropis) tapeina was confined to the altitude of $1700 \mathrm{~m}$ in the east which was covered with stones and decayed leaves. Their shells were found at wet and rocky places of the forest.

Four species of terrestrial mollusc of Ariophantidae were found interesting in their distribution as they shared their habitats both in the lowland and midland regions. These include Macrochlamys lubrica, Rotungia williamsoni, Cryptaustenia ovum and Taphrespira compluvialis, the former second one was reported at rocky places of Kailali and Kanchanpur districts. The rest three species were found in the low land and midland regions of east Nepal.

Laevicaulis alte (Black Slug) was collected from various localities of Morang, Dang, Banke, Kailali and Kanchapur districts. It was found in wet and moist areas in association with algal plants. The occurrence of Opeas sp. was confined to Morang district only. Its report was made outside the kitchen and was climbing and approaching to the damp areas covered with vegetations like algae and mosses. Bacillium $\mathrm{sp}$. was found at stony beds of cardamom gardens of the Panchthar and llam districts in the east.

Glessula tenuispira and Aegista (placetotropis) tapeina were also collected from Panchthar and Ilam districts of the east. These were not recorded in Kailali, Kanchanpur and Dang districts of the west.

The climate and vegetation are important abiotic and biotic components which play crucial role for the distribution of molluscan species in a particular area. Most of the plant species of eastern Nepal are not available in the west, besides the amount of rainfall which is said to be an important factor for the distribution of molluscan species is lesser in west, comparative to 
the eastern region. It may be one of the reasons why the eastern molluscan species are rare and many of them are not found in the western parts of the country (Table - I).

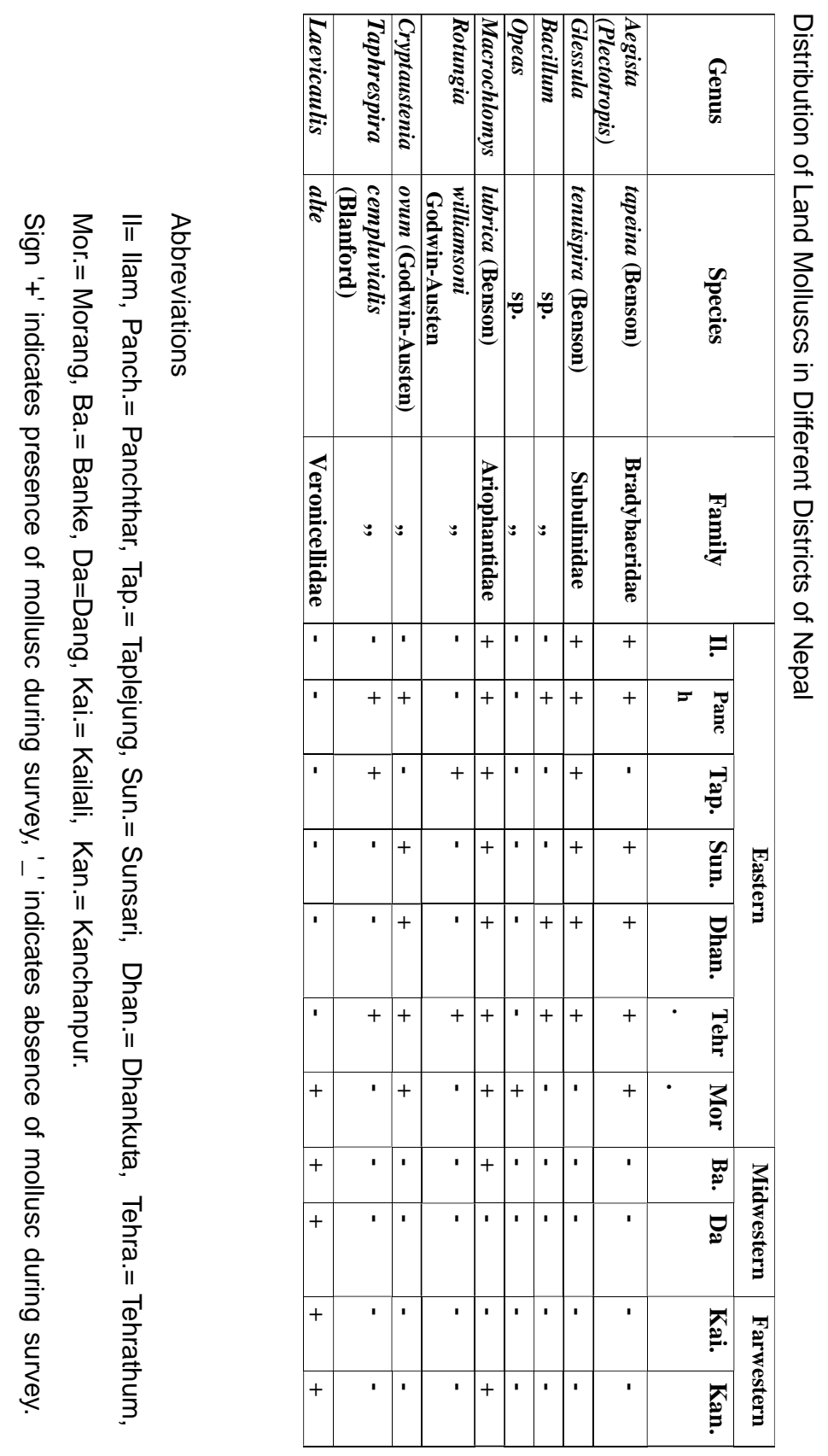




\section{Acknowledgements}

We would like to thank to the Director of Zoological Survey of India, Calcutta, for his kind help in identification work. Our special thanks are due to the villagers who not only guided us upto the collection sites but also helped us to collect molluscan specimens at different places not accessible to us.

\section{References}

Cooke, A.H., A.E. Shipley and F.R. Reed (1896). Molluscs, Brachiopod In: The Cambridge Natural History, III Repr. (1968). S.F., Harmer and A.E. Shipley (eds), Macmillan \& Co. Ltd. England:459 .

Godwin-Austen, H.H. (1910). Land and Freshwater mollusca of India including south Arabia Baluchistan, Kashmir, Nepal, Burma, Pegu Tenasserim, Malay Peninsula, Ceylon and other islands of Indian ocean, Supplementary to Theobald and Hanley's Conchologia India, 2, PI, XI, London.

Hyman, L.H. (1993). The invertebrate's volume V.I Mollusca, 1:792 CBS publishers and distributors India.

Majupuria, T.C. (1981-1982). Wild is beautiful. Introduction to Fauna and Wildlife of Nepal. S. Devi. Gwalior, India:507

Pefiffer, M., S. Sharma and B.M. Dahal (1999). Age and population structure of fresh water mussel in the lowland rivers of Nepal Proceedings of III. National conference on science and Technology:371-1377

Raut, S.K. and K.C. Ghose (1984). Pestiferous Land snails of India Ed. Director, Zoological Survey of India, Calcutta:151.

Subba, B.R. and T.K. Ghosh (2000). Some freshwater molluscs from eastern and central Nepal. J. Bombay Nat. Hist. Soc., 97(3):452-455.

Subba, B.R. and T.K. Ghosh (2001). Terrestrial molluscs from eastern and central Nepal. J. Bombay Nat. Hist. Soc., 98(1):58-61.

Subba, B.R. (2003). Molluscan Check list of Ghodaghodi Tal Area, Kailali district, Our Nature. 1:1-2. Subba, B.R. and M.R. Pandey (2005). Molluscan diversity of Jhapa district, eastern Nepal. J.Nat. Hist. Mus., 22:22-27.

Thapa, D. (2003). Molluscan diversity of Koshi Tappu Wildlife Reserve and its surrounding area. Our Nature, 1:73-74.

Yadav, U.K.R., S.B. Karki and P.N. Mishra (1980). Population studies of freshwater snails of a lake and three ponds of Kathmandu valley Nepal, J. Nat. Hist. Mus., 4(1).

\section{Author's Address}

${ }^{1}$ Dr. Bharat Raj Subba and Mr. Tapan Kumar Ghosh

${ }^{1}$ Department of Zoology, Post Graduate Campus, Biratnagar, Nepal

Department of Zoology, T.M. Bhagalpur University, India 